This article was downloaded by: [The University of Edinburgh]

On: 22 December 2014, At: 04:35

Publisher: Routledge

Informa Ltd Registered in England and Wales Registered Number: 1072954 Registered office: Mortimer House, 37-41 Mortimer Street, London W1T 3JH, UK

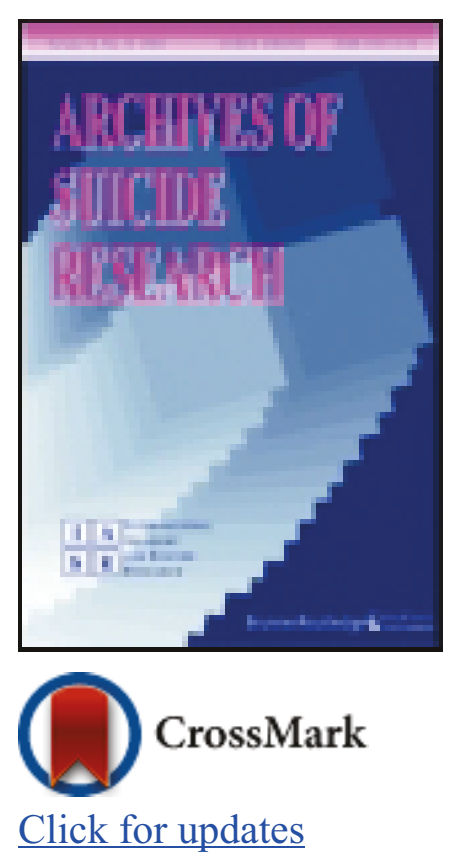

\title{
Archives of Suicide Research
}

Publication details, including instructions for authors and subscription information:

http://www.tandfonline.com/loi/usui20

\section{Differences in Physicians' and Nurses' Recent Suicide Attempts: An Exploratory Study}

María Dolores Braquehais ${ }^{\mathrm{ab}}$, Francisco José Eiroa-Orosa ${ }^{\mathrm{c}}$, Kristin M. Holmes ${ }^{\mathrm{d}}$, Pilar Lusilla ${ }^{\mathrm{b}}$, Maria Bravo ${ }^{a}$, Xulián Mozo ${ }^{a}$, Marcela Mezzatesta ${ }^{e}$, Marta Casanovas $^{f}$, Tània Pujol ${ }^{a} \&$ Leo Sher ${ }^{d}$

a Integral Care Program for Sick Health Care Professionals, Galatea Clinic, Department of Health of the Generalitat of Catalonia, Barcelona, Spain \& Galatea Foundation, Col-legi de Metges de Barcelona, Barcelona, Spain

${ }^{b}$ Department of Psychiatry and Legal Medicine, Vall d'Hebron University Hospital, CIBERSAM, Universitat Autònoma de Barcelona, Barcelona, Spain

c School of Psychology, University of East London, Stratford, United Kingdom

'd Department of Psychiatry, James J. Peters' Veterans Administration Medical Center and Department of Psychiatry, Mount Sinai School of Medicine, New York, USA

${ }^{\mathrm{e}}$ Child and adolescent Mental Health Unit, Fundació Orienta, Fundació Salut i Comunitat, Barcelona, Spain

${ }^{f}$ The Centre for Mental Health, Hammersmith Hospital Campus, Imperial College, London, United Kingdom

Accepted author version posted online: 17 Dec 2014.

To cite this article: María Dolores Braquehais, Francisco José Eiroa-Orosa, Kristin M. Holmes, Pilar Lusilla, Maria Bravo, Xulián Mozo, Marcela Mezzatesta, Marta Casanovas, Tània Pujol \& Leo Sher (2014): Differences in Physicians' and Nurses' Recent Suicide Attempts: An Exploratory Study, Archives of Suicide Research, DOI: 10.1080/13811118.2014.996693

To link to this article: http://dx.doi.org/10.1080/13811118.2014.996693

Disclaimer: This is a version of an unedited manuscript that has been accepted for publication. As a service to authors and researchers we are providing this version of the accepted manuscript (AM). Copyediting, typesetting, and review of the resulting proof will be undertaken on this manuscript before final publication of the Version of Record (VoR). During production and pre-press, errors may be discovered which could affect the content, and all legal disclaimers that apply to the journal relate to this version also.

\section{PLEASE SCROLL DOWN FOR ARTICLE}

Taylor \& Francis makes every effort to ensure the accuracy of all the information (the "Content") contained in the publications on our platform. However, Taylor \& Francis, our agents, and our licensors make no representations or warranties whatsoever as to the accuracy, completeness, or suitability for any purpose of the Content. Any opinions and views expressed in this publication are the opinions and views of the authors, and are not the views of or endorsed by Taylor \& Francis. The accuracy of the Content should not be relied upon and should be independently verified with primary sources of information. Taylor and Francis shall not be liable for any losses, actions, claims, proceedings, demands, costs, expenses, damages, and other liabilities whatsoever or howsoever caused arising directly or indirectly in connection with, in relation to or arising out of the use of the Content.

This article may be used for research, teaching, and private study purposes. Any substantial or systematic reproduction, redistribution, reselling, loan, sub-licensing, systematic supply, or distribution in any 
form to anyone is expressly forbidden. Terms \& Conditions of access and use can be found at http:// www.tandfonline.com/page/terms-and-conditions 


\title{
Differences in Physicians' and Nurses' Recent Suicide Attempts: An Exploratory Study
}

María Dolores Braquehais ${ }^{1,2}$, Francisco José Eiroa-Orosa ${ }^{3}$, Kristin M. Holmes ${ }^{4}$, Pilar Lusilla $^{2}$, Maria Bravo ${ }^{1}$, Xulián Mozo ${ }^{1}$, Marcela Mezzatesta ${ }^{5}$, Marta Casanovas ${ }^{6}$, Tània Pujol $^{1}$, Leo Sher ${ }^{4}$

${ }^{1}$ Integral Care Program for Sick Health Care Professionals, Galatea Clinic, Department of Health of the Generalitat of Catalonia, Barcelona, Spain \& Galatea Foundation, Col-legi de Metges de Barcelona, Barcelona, Spain, ${ }^{2}$ Department of Psychiatry and Legal Medicine, Vall d'Hebron University Hospital, CIBERSAM, Universitat Autònoma de Barcelona, Barcelona, Spain, ${ }^{3}$ School of Psychology, University of East London, Stratford, United Kingdom, ${ }^{4}$ Department of Psychiatry, James J. Peters' Veterans Administration Medical Center and Department of Psychiatry, Mount Sinai School of Medicine, New York, USA, ${ }^{5}$ Child and adolescent Mental Health Unit, Fundació Orienta, Fundació Salut i Comunitat, Barcelona, Spain, ${ }^{6}$ The Centre for Mental Health, Hammersmith Hospital Campus, Imperial College, London, United Kingdom

Address correspondence to: María Dolores Braquehais, M.D., Ph.D., Clinical Director, Inpatient Psychiatry Unit for Health Professionals, Galatea Clinic, Galatea Foundation, Integral Care Program for Sick Health Care Professionals, Passeig Bonanova, 47, 08017 Barcelona, Spain, Email: mdbraquehais.paimm@comb.cat; mdbraquehais@vhebron.net

\author{
Abstract \\ Aim: To examine the characteristics of physicians' and nurses' suicide attempts (SA). \\ Method: A retrospective review of 493 medical records of physicians and nurses admitted \\ to an inpatient unit for health professionals; 36 patients had a recent SA. \\ Results: Depression, cluster B and C personality disorders, and a history of previous SA \\ were more prevalent in patients with a recent SA compared to those without it. Both \\ professional groups preferred drug overdose as a suicide method. Physicians made more \\ lethal attempts and had a history of more previous stressors than nurses. \\ Conclusion: Depression, cluster B and C personality disorders, and previous SA should
}


be appropriately screened and treated in order to prevent SA amongst physicians and nurses.

KEYWORDS: suicide attempts; physicians; nurses

\section{INTRODUCTION}

Suicide risk in physicians or nurses is elevated compared to the general population (Aasland, Ekeberg \& Shweder 2001; Aasland, Hem, Haldorsen et al., 2011; Center, Davis, Detre et al., 2003; Gold, Frost-Pineda; Hawton, Clements, Sakarovicht et al., 2001; Hawton, Agerbo, Simkin, 2011; Pompili, Rinaldi, Lester et al., 2006;

Schernhammer \& Colditx, 2004; Schwenk, Davis \& Wimsatt, 2010; Kolves \& De Leo, 2013; Gold, Sen, Schwenk, 2013).

To our knowledge, data on physicians and/or nurses admitted to a Psychiatric Unit after a suicide attempt is limited. Therefore, the aim of this study was to explore the main features of physicians' and nurses' recent suicide attempts (RSA). Based on the existing literature of completed suicides in both populations, we hypothesized that the characteristics of suicide attempts may be similar in these two groups. This could be explained by the fact that physicians and nurses have a somewhat similar education and training. In addition, drugs are available to both groups, i.e., both groups have access to lethal means. From an occupational perspective, physicians and nurses may be exposed to similar stressors. In this study, we examined demographic and clinical characteristics of suicide attempters. If suicide attempts have similar patterns in physicians and nurses, 
clinicians should adopt analogous treatment and preventive strategies to reduce suicidal behaviour in both professional groups.

\section{METHODS}

\subsection{Setting}

The Physicians' Health Program (PHP) of Barcelona was created jointly by the Department of Health of the Regional Government of Catalonia and the Catalan "Colegio de Médicos" in 1998. In 2000, the program was extended to nurses. Both programs belong to the Barcelona Integral Care Program for Sick Health Care Professionals. The main aim of the Program is to assist medical professionals who have substance use disorders and/or from other mental disorders, to prevent mental distress, and to help them go back to professional practice (Braquehais, Valero, Matalí et al., 2014).

In Spain, "medical associations" and "medical councils/regulatory bodies" are part of the same institution ("Colegio de Médicos" in Spanish) where all practicing physicians need to be registered. Nurses need to be affiliated to similar institutions ("Colegio de Enfermeria" in Spanish).

Physicians and nurses from all regions of Spain can be referred to the Barcelona inpatient unit when severe mental disorders are identified.

\subsection{Participants}


We conducted a retrospective chart review of 493 medical records of physicians and nurses who had been admitted to the Barcelona Psychiatric Inpatient Unit from January 1999 to January 2008. Reports of patients admitted after RSA (within one month before the index admission) were identified $(\mathrm{n}=36)$. Patients who had a RSA could be referred by another hospital (mainly after a severe RSA) once their medical condition was stabilized.

\subsection{Instruments}

\subsubsection{Clinical And Demographic Data}

Demographic data obtained at admission included sex, age, marital status, and professional status (physicians vs. nurses). The main diagnosis at admission was determined by a psychiatrist according to DSM-IV criteria (American Psychiatric Association, 2000). Affective disorders were divided into two groups: unipolar affective disorders (including major depressive episode, recurrent depressive disorder and dysthimia) ) and bipolar affective disorders.

\subsubsection{Suicidal Behavior}

A suicide attempt was defined as a self-destructive behavior with the intent to end one's life, independent of the resulting damage (O'Carroll, Berman, Maris et al., 2001). Data about RSA and lifetime suicide attempts (LSA) were obtained from medical records.

Specific information on patients admitted after a RSA included several features: 
1) Method and lethality were retrospectively defined using the Lethality Rating Scale, LRS (Beck, Resnik \& Lettieri, 1974). The LRS registers the type of method used and rates the medical consequences of different suicide methods ranging between 0 (no consequences) and 8 (death). A score $\geq 4$ suggests a "high lethality" attempt and indicates the need for major medical interventions to treat the patient. Attempts were classified dichotomously as having high lethality or low lethality according to this observation.

2) Triggers for suicidal behavior were classified according to the Axis IV classification of psychosocial and environmental problems (APA, 2000) into the following groups: problems with primary support group, problems related to the social environment, occupational problems, financial problems, problems related to interaction with the legal system/crime, and other psychosocial and environmental problems.

\subsection{Statistical Analysis}

Odds ratios and $95 \%$ confidence intervals were used to compare dichotomous variables between groups. T tests were used to compare continuous variables. All hypothesis tests were two-tailed and conducted with an alpha of 0.05 . We did not perform a multivariate analysis due to the small sample size. All analyses were performed using SPSS version 18 (Chicago, IL).

\section{RESULTS}

Physicians ( $38.52 \pm 8.39$ vs. $45.68 \pm 8.52$ years) and nurses ( $40.53 \pm 10.03$ vs. $46.07 \pm 7.16$ years) with RSA were younger compared to those without it, although the difference was 
statistically significant only in the case of physicians. No statistically significant differences were found in the mean age of physicians and nurses with RSA.

Both female physicians and nurses were more likely to have attempted suicide $(\mathrm{OR}=3.252 ; 95 \% \mathrm{CI}=1.562-6.770)$. Likewise, a higher proportion of women was found among physicians with RSA compared to physicians without RSA (OR=3.138; $95 \%$ $\mathrm{CI}=1.269-7.763)$ but not among nurses with RSA $(\mathrm{OR}=1.123 ; 95 \% \mathrm{CI}=0.282-4.469)$. With regards to marital status, no statistically significant differences were found between physicians and nurses.

Patients with a RSA more frequently had a history of previous suicide attempts compared to patients without $\mathrm{RSA}(\mathrm{OR}=11.364 ; 95 \% \mathrm{CI}=5.361-24.086)$. No differences in their previous suicidal history were found between physicians and nurses with RSA.

With regard to their main diagnosis at admission, both physicians and nurses with unipolar affective disorders were more likely to have a RSA compared to those admitted for other reasons $(\mathrm{OR}=4.672 ; 95 \% \mathrm{CI}=2.271-9.610)$. Patients with RSA more frequently had cluster $\mathrm{B}$ personality disorders $(\mathrm{OR}=3.315 ; 95 \% \mathrm{CI}=1.267-8.764)$ and cluster $\mathrm{C}$ personality disorders $(\mathrm{OR}=6.833 ; 95 \% \mathrm{CI}=1.635-28.562)$ compared to those without RSA. Patients with alcohol use disorders were admitted for other reasons than a RSA $(\mathrm{OR}=0.349 ; 95 \% \mathrm{CI}=0.171-0.716)$ No statistically significant differences were found between physicians and nurses with RSA with regard to their main diagnosis. 
Table 1 illustrates differences in RSA characteristics between physicians and nurses. A greater proportion of nurses (20.54\%) were admitted after RSA compared to physicians (5.5\%). Statistically significant differences between physicians and nurses were only found for the lethality of the attempt and in the number of psychosocial and environmental problems prior to the attempt. Nurses more frequently recognized one single stressor before the attempt and made "less lethal" attempts compared to physicians.

\section{DISCUSSION}

The present work is the first study that examines both the social, clinical and suicidiological features of physicians and nurses who had been admitted to a psychiatric unit after a RSA. Although both groups shared some risk factors (history of previous suicide attempts, diagnosis of depression and cluster B or C personality disorders) our results point to some differences in their suicidal behaviour.

Recent attempts were more frequent among women physicians. This same gender effect has been observed in completed suicides among physicians (Schernhammer \& Colditx, 2004). However, our findings are consistent with observations on suicide attempts in the general population that show a higher prevalence in women (Weisman, Bland, Canino et al., 1999). On the other hand, little is known with regard to the gender effect among nurses because suicidal behaviour was mostly studied in women nurses (Hawton \& Vislisel, 1999; Hawton, Agerbo \& Simkin, 2011; Pompili, Rinaldi, Lester et al., 2006; Kolves \& De Leo, 2013). Our observations are not conclusive in this point. 
Physicians with RSA in our study tended to be younger than those without an attempt, but their age was similar to that observed for completed suicide in physicians (Center, Davis, Detre et al., 2003). With regard to the main diagnosis at admission, unipolar affective disorders, and/or cluster $\mathrm{B}$ and $\mathrm{C}$ personality disorders predicted suicide attempts in our study. Various studies support the relationship between depression, personality disorders, and suicide both among physicians and nurses (Center, Davis, Detre et al., 2003; Hawton, Agerbo and Simkin, 2011; Pompili, Rinaldi, Lester et al., 2006). However, in our study we observed an inverse relationship between alcohol use disorders and suicidal behavior (alcohol use disorders were more prevalent among patients without RSA). This unexpected finding could be explained because patients with alcohol use disorders were overrepresented in the original sample. Health professionals were more likely to be referred to the inpatient unit because of alcohol disorders since problems of this nature are frequently related to malpractice issues and lead to psychiatric admissions. This fact may explain the discordances of our results with those of previous studies that support the role of alcohol consumption as a risk factor for suicide in both professional groups (Center, Davis, Detre et al., 2003; Hawton \& Vislisel, 1999).

Finally, when comparing physicians and nurses suicide attempters, we found no differences in the mean age and in their main diagnosis at admission. However, the lethality and the number of stressors prior to the RSA were different in both groups. The method most commonly used by physicians and nurses was a psychotropic drug overdose followed by non-psychotropic drug overdose which is most likely because of the availability and knowledge of drugs as lethal means by both groups (Hawton \& Vislisel, 
1999; Center, Davis, Detre et al., 2003). But physicians seemed to need more than one stressor to attempt suicide and their attempts were more lethal than those made by nurses.

Some limitations of this study must be noted: 1) this is a preliminary, retrospective, exploratory study that was conducted based on a review of medical records; 2) the inpatient unit most prevalent diagnoses were substance use disorders (mainly, alcohol use disorders) and this fact led to a bias when comparing the diagnosis of patients admitted after a RSA with that of those admitted for other reasons; 3 ) subjects with RSA were not matched based on demographic and clinical parameters; 4) the sample size of RSA was too small to reach enough power to do many comparisons, to perform multivariate analysis and it also lead to large confidence intervals, thus leading to less precise results; and, 5) we have to be careful in generalizing our results to other contexts (such as other countries).

Moreover, the conclusions of this study should be limited to health professionals who were hospitalized after their suicide attempt and were finally referred to our specialized inpatient unit. We cannot ignore that some suicidal patients may not seek help after their attempt. The lack of information about comorbid conditions (only one main diagnosis was registered at the clinical record) also limits the clinical implications of our results. Despite the limitations of this study, we believe these preliminary findings should be considered in future treatment and preventive interventions of suicidal behavior in physicians and nurses. 


\section{ACKNOWLEDGMENTS}

We would like to thank the members of Galatea Foundation and of the Col·legi de Metges de Barcelona for their constant support in the development and maintenance of the Integral Care Program for Sick Health Professionals of Barcelona.

\section{REFERENCES}

American Psychiatric Association (2000). Diagnostic and Statistical Manual of Mental

Disorders, 4th ed. Text Revision (DSM-IV-TR). Washington: American Psychiatric Association.

Aasland, O.G. Ekeberg, O., Schweder, T. (2001). Suicide rates from 1960 to 1989 in Norwegian physicians compared with other educational groups. Social Science \& Medicine, 52, 259-65.

Aasland, O.G., Hem, E., Haldorsen, T., Ekeberg, Ø. (2011). Mortality among Norwegian doctors 1960-2000. BMC Public Health, 11, 173.

Beck, A.T., Resnik, H.L.P., Lettieri, D.J. (1974). The prediction of suicide. Maryland: Charles Press Plublishers.

Braquehais, M.D., Valero, S., Matalí, J.L., Bel, M.J., Montejo, J.E., Nasillo, V., Arteman, A., Padrós, J. Bruguera, E., Casas, M. (2014). Promoting voluntary help seeking among doctors with mental disorders. International Journal of Occupational Medicine and Environmental Health, 27, 435-443.

Center, C., Davis, M., Detre, T., Ford, D.E., Hansbrough, W., Hendin, H., Laszlo, J., Litts, D.A., Mann, J., Mansky, P.A., Michels, R., Miles, S.H., Proujansky, R., Reynolds, C.F. 3rd, Silverman, M.M. (2003). Confronting depression and suicide in physicians: a 
consensus statement. JAMA: The Journal of the American Medical Association, 289, $3161-6$.

Gold, K.J., Sen, A., Schwenk, T.L. (2013). Details on suicide among US physicians: data from the National Violent Death Reporting System. General Hospital Psychiatry, 35, 459.

Hawton, K., Vislisel, L. (1999). Suicide in nurses. Suicide and Life Threatening Behaviors, 29, 86-95.

Hawton, K., Clements, A., Sakarovitch, C., Simkin, S., Deeks, J.J. (2001). Suicide in doctors: a study of risk according to gender, seniority and specialty in medical practitioners in England and Wales, 1979-1995. Journal of Epidemiology and Community Health, 55, 296-300.

Hawton, K., Agerbo, E., Simkin, S. (27011). Risk of suicide in medical and related occupational groups: a national study based on Danish case population-based registers. Journal of Affective Disorders, 134, 320-6.

Kolves, K., De Leo, D. (2013) Suicide in medical doctors and nurses: an analysis of the Queesland Suicide Register. Journal of Nervous and Mental Disease, 201, 987-90.

O’Carroll, P.W., Berman, A.L., Maris, R.W., Moscicki, E.K., Tanney, B.L., Silverman, M.M. (2001). Beyond the Tower of Babel: a nomenclature for suicidology. Suicide and Life Threatening Behaviors, 26, 235-237.

Pompili, M., Rinaldi, G., Lester, D., Girardi, P., Ruberto, A., Tatarelli, R. (2006).

Hopelessness and suicide risk emerge in psychiatric nurses suffering from burnout and using specific defence mechanisms. Archives of Psychiatric Nursing, 20, 135-43. 
Schernhammer, E.S., Colditx, G.A. (2004). Suicide rates among physicians: A quantitative and gender assessment (Meta-Analysis). American Journal of Psychiatry, $161,2295-2302$.

Schwenk, T.L., Davis, L., Wimsatt, L.A. (2010). Depression, stigma, and suicidal ideation in medical students. JAMA: the Journal of the American Medical Association, 304, 1181-1190. 
Table 1. Recent suicide attempt characteristics by professional group

\begin{tabular}{|c|c|c|c|c|c|c|c|c|}
\hline \multirow[t]{2}{*}{ Variables } & & sicia & \multicolumn{2}{|c|}{ Nurses } & \multicolumn{2}{|c|}{ Statistics } & \multicolumn{2}{|c|}{ TOTAL } \\
\hline & $\mathrm{n}$ & $\%$ & $\mathrm{n}$ & $\%$ & OR & $95 \% \mathrm{CI}$ & & \\
\hline $\begin{array}{l}\text { Lethality Rating Scale (LF } \\
\text { score }\end{array}$ & & & & & & & & \\
\hline$<4$ & 11 & $\begin{array}{l}52 . \\
4\end{array}$ & 14 & $\begin{array}{l}93 . \\
3\end{array}$ & $\begin{array}{l}0.07 \\
9\end{array}$ & $\begin{array}{l}0.009= \\
0.711\end{array}$ & 25 & 69.4 \\
\hline$\geq 4$ & 10 & 47. & 1 & 6.7 & & & 11 & 30.6 \\
\hline Method (LRS defined)* & & & 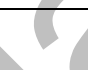 & & & & & \\
\hline Cuts & 2 & 9.5 & 4 & $\begin{array}{l}26 . \\
7\end{array}$ & $\begin{array}{l}0.28 \\
9\end{array}$ & $\begin{array}{l}0.045- \\
1.846\end{array}$ & 6 & 16.7 \\
\hline Weapons & 1 & 4.8 & 0 & 0 & $* *$ & $* *$ & 1 & 2.8 \\
\hline Psychotropic drugs & 15 & 71. & 15 & 100 & $* *$ & $* *$ & 29 & 83.3 \\
\hline Non psychotropic drugs & 8 & $\begin{array}{l}38 . \\
1\end{array}$ & 4 & $\begin{array}{l}26 . \\
7\end{array}$ & $\begin{array}{l}1.69 \\
2\end{array}$ & $\begin{array}{l}0.399- \\
7.12\end{array}$ & 12 & 32.4 \\
\hline Alcohol & 3 & $\begin{array}{l}14 . \\
3\end{array}$ & 3 & 20 & $\begin{array}{l}0.66 \\
7\end{array}$ & $\begin{array}{l}0.115- \\
3.872\end{array}$ & 5 & 16.7 \\
\hline Number of methods & & & & & $\begin{array}{l}3.00 \\
0\end{array}$ & $\begin{array}{l}0.759- \\
11.864\end{array}$ & & \\
\hline 1 & 14 & 66. & 6 & 40 & & & 20 & 55.6 \\
\hline
\end{tabular}




\begin{tabular}{|c|c|c|c|c|c|c|c|c|}
\hline & & 7 & & & & & & \\
\hline More than one & 7 & $\begin{array}{l}33 . \\
3\end{array}$ & 9 & $\begin{array}{l}60 . \\
0\end{array}$ & & & 13 & 36.1 \\
\hline $\begin{array}{l}\text { \% With psychotropic + non } \\
\text { psychotropic drugs }\end{array}$ & 4 & $\begin{array}{l}19 . \\
0\end{array}$ & 4 & $\begin{array}{l}26 . \\
7\end{array}$ & $\begin{array}{l}0.64 \\
7\end{array}$ & $\begin{array}{l}0.133- \\
3.141\end{array}$ & 8 & 22.2 \\
\hline $\begin{array}{l}\text { Psychosocial and } \\
\text { Environmental Problems (DS } \\
\text { IV - Axis IV) * }\end{array}$ & & & & & & & & \\
\hline $\begin{array}{l}\text { Problems with primary support } \\
\text { group }\end{array}$ & 16 & $\begin{array}{l}76 . \\
2\end{array}$ & 12 & $\begin{array}{l}80 . \\
0\end{array}$ & 0.80 & $\begin{array}{l}0.159- \\
4.023\end{array}$ & 28 & 77.8 \\
\hline $\begin{array}{l}\text { Problems related to the social } \\
\text { environment }\end{array}$ & 4 & 19. & 0 & 0 & ** & ** & 4 & 11.1 \\
\hline Occupational problems & 8 & 38. & 1 & 6.7 & $* *$ & $* *$ & 9 & 25.0 \\
\hline Economic problems & 1 & 4.8 & 1 & 6.7 & ** & ** & 2 & 5.6 \\
\hline $\begin{array}{l}\text { Problems related to } \\
\text { interaction_legal system/crime }\end{array}$ & 2 & 9.5 & 0 & 0 & ** & ** & 2 & 5.6 \\
\hline $\begin{array}{l}\text { Other psychosocial and } \\
\text { environmental problems }\end{array}$ & 3 & $\begin{array}{l}15 . \\
8\end{array}$ & 3 & $\begin{array}{l}20 . \\
0\end{array}$ & $\begin{array}{l}0.75 \\
0\end{array}$ & $\begin{array}{l}0.128- \\
4.389\end{array}$ & 6 & 17.6 \\
\hline $\begin{array}{l}\text { Number of Psychosocial and } \\
\text { Environmental Problems }\end{array}$ & & & & & & & & \\
\hline 1 & 9 & $\begin{array}{l}42 . \\
9\end{array}$ & 13 & $\begin{array}{l}86 . \\
7\end{array}$ & $\begin{array}{l}0.11 \\
5\end{array}$ & $\begin{array}{l}0.021- \\
0.645\end{array}$ & 22 & 61.7 \\
\hline
\end{tabular}




\begin{tabular}{|l|l|l|l|l|l|l|l|l|}
\hline More than one & 12 & 57. & 2 & 13. & & & 14 & 38.9 \\
& & 1 & & 3 & & & & \\
\hline
\end{tabular}

* Non-exclusive variables

**Statistical comparison tests were not performed due to low $\mathrm{n}$ in cross table cells

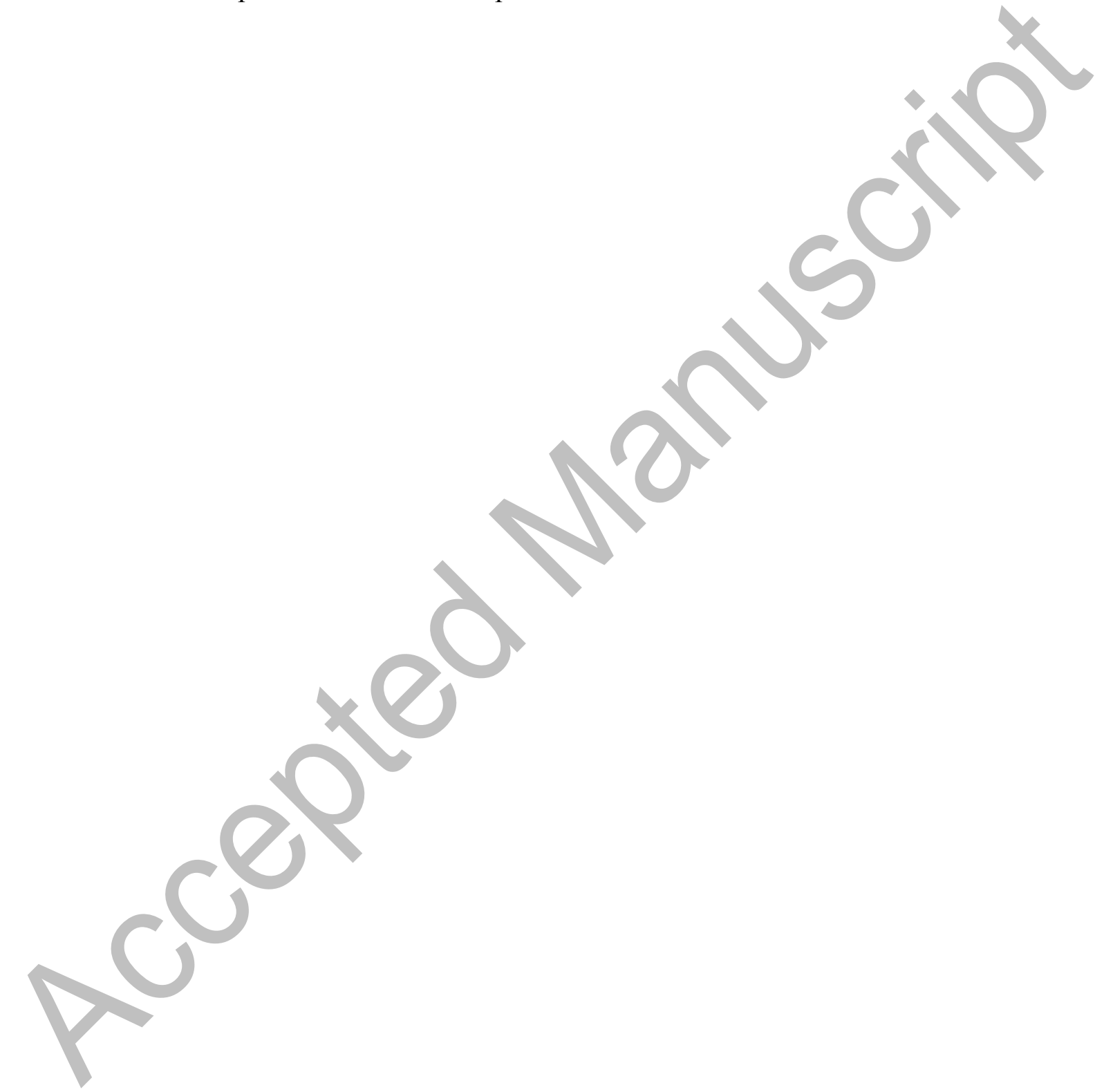

